\title{
27. BOREHOLES AT GREAT ISAAC AND SITE 626 AND THE HISTORY OF THE FLORIDA STRAITS ${ }^{1}$
}

\author{
Wolfgang Schlager, ${ }^{2}$ Feodor Bourgeois, ${ }^{3}$ Greta Mackenzie, ${ }^{4}$ and Jan Smit ${ }^{2}$
}

\begin{abstract}
We examined the stratigraphy of the top $2100 \mathrm{~m}$ of the Great Isaac 1 well, tied it to recent seismic surveys of the area, and correlated it with ODP Site $626,60 \mathrm{~km}$ to the southwest. The succession at Great Isaac includes shallow-water carbonate-evaporite deposits (mid-Cretaceous and older) overlain by deep-water deposits with upward-increasing neritic debris (Late Cretaceous-Tertiary) and capped by bank-margin deposits (Plio-Pleistocene). This succession is interpreted as a restricted carbonate platform that was drowned in the late Albian or Cenomanian, subsided to over $600 \mathrm{~m}$ water depth, and was subsequently reintegrated into Great Bahama Bank by westward progradation of the platform. Seismic surveys support this interpretation. The carbonate-evaporite platform appears as high-amplitude parallel reflections, the pelagic chalk as parallel-layered drape over the platform, and the slope as prograding clinoforms where coherence of reflections decreases upward with decreasing distance from the platform; the bank margin is a zone of incoherent reflections.

In the late Oligocene and Miocene, ODP Site 626 and Great Isaac display almost identical deep-water facies and horizontal time lines, suggesting that both sites lay in the Florida Straits at the same water depth. The older section was not recovered at Site 626, but parallel time lines and similar depositional history are also indicated for the Paleogene and Late Cretaceous: the top of the drowned platform at Great Isaac, which is a high-amplitude seismic reflector there, coincides in depth with the target reflector at Site 626, interpreted on seismostratigraphic grounds as a drowned platform.

Borehole stratigraphy and seismic profiles at Great Isaac and Site 626 clearly show that the present margin of Great Bahama Bank in this area is controlled not by tectonics but by platform progradation and that the drowned Cretaceous platform recovered at Great Isaac also underlies the Florida Straits in this area. Both observations strongly support the hypothesis that until the mid-Cretaceous, Florida and the Bahamas were welded into a single vast platform, the megabank.
\end{abstract}

\section{INTRODUCTION}

The origin of the intricate pattern of platforms and basins is a recurring theme in geologic research on the Bahamas. Two lines of thought can be distinguished. One considers the pattern to be old and rooted either in an early Mesozoic drainage system (Hess in Talwani et al., 1960) or in fault-bounded grabens (Talwani et al., 1960; Mullins and Lynts, 1977). The other group of hypotheses claims that these early Mesozoic structures were leveled by a vast carbonate platform in the Late Jurassic and Early Cretaceous and that the present pattern of banks and basins is a young feature, established on top of the Jurassic-Cretaceous platform, the "megabank," during the Cretaceous (Meyerhoff and Hatten, 1974; Sheridan et al., 1981; Schlager and Ginsburg, 1981).

The scientific prospectus of Leg 101 called for testing the megabank hypothesis by drilling to the postulated (mid-Cretaceous) top of the megabank under one of the basins. Confirmation of the facies change from shallow- to deep-water deposits would prove the megabank hypothesis; failure to do so would tip the balance in favor of deep-rooted basins, even though definite proof of the graben hypothesis would require drilling beyond ODP capabilities.

ODP Site 626 in the Florida Straits was designed for this test but failed to reach the target horizon. However, as pointed out

\footnotetext{
${ }^{1}$ Austin, J. A., Jr., Schlager, W., et al., 1988. Proc. ODP, Sci. Results, 101: College Station, TX (Ocean Drilling Program).

2 Institute for Earth Sciences, Free University, P.O. Box 7161, 1007 MC Amsterdam, The Netherlands.

33120 Ptarmigan Drive \#2, Walnut Creek, CA 94595.

4 University of Miami, Fisher Island Station, Miami, FL 33139.
}

by Austin, Schlager, et al. (1986), the Great Isaac well can be used as a proxy for the missing section at Site 626 (Fig. 1). In this chapter we document the stratigraphy at Great Isaac from the top to just below the target horizon, establish time lines between the two wells, compare the facies succession, and tie seismic profiles to the Great Isaac well. Finally, we evaluate the results with regard to the growth history of the Bahama Banks.

\section{METHODS}

This study relies primarily on examination of approximately 600 thin sections from cuttings and sidewall cores from the Great Isaac 1 well, drilled by Bahama-California Oil Co. (Chevron) 1970-71. For additional well data we used wireline logs and drilling reports and lithologic descriptions at the well site. For ODP Site 626, we used the Site Chapter in Austin, Schlager, et al. (1986), as well as visual core descriptions by the Shipboard Scientific Party. The correlation with seismics is based on copies of lines $5 \mathrm{~A}-\mathrm{N}, 5-\mathrm{N}$, and 7-N provided by Texaco Latin America, Inc. Lines were shot with a tuned air-gun array (volumes $720-2880$ in $^{3}$ ) at $50-\mathrm{m}$ intervals. On the banks, the cable was lowered to the seafloor between shots.

\section{RESULTS}

\section{Stratigraphy and Sedimentology at Great Isaac 1}

From bottom to top, the examined interval of the Great Isaac well displays a succession of shallow-water carbonate-evaporite deposits, followed by deep-water chalks with upward-increasing neritic detritus to platform-margin deposits at the top (Fig. 2). Biostratigraphy indicates that the carbonate-evaporite sequence is mid-Cretaceous, the deep-water chalks are mid-Cretaceous through Miocene, and the shallow-water units at the top are Miocene or younger. Several features in this succession merit discussion. We will present them from bottom to top. 


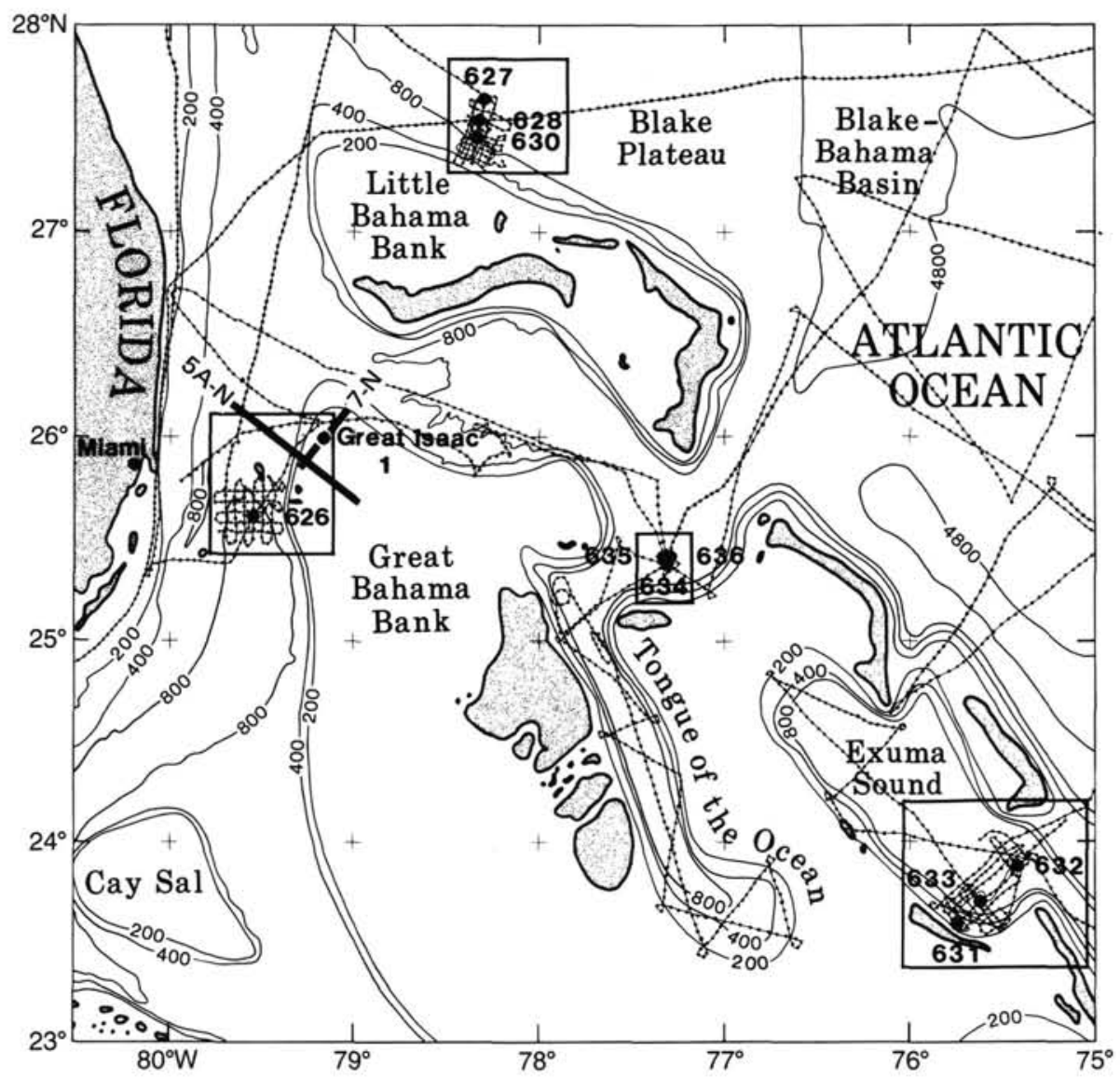

Figure 1. Location map of Great Isaac 1 well, ODP Site 626, and seismic lines 7-N and 5A-N shown in this report.

The upper $200 \mathrm{~m}$ of the Cretaceous platform sequence is devoid of evaporites. It remains open if the evaporites were leached during the subsequent drowning of the platform or if they were primarily absent because of more open-marine conditions in this interval. A similar but continuously cored section at Site 627 on Blake Plateau suggests that the absence of evaporites is a primary feature. More open circulation in this interval may have heralded the drowning of the platform.

Layers of silt- and sand-sized quartz are common in the dolomites. They indicate terrigenous influx by bedload transport and strongly suggest that the platform was attached on one side to land. On detached platforms such as the present-day Bahama Banks, this influx is reduced to minimal quantities of windblown silt.

The drowning event itself can be bracketed as Albian through Turonian. Better control at Site 627 indicates drowning in the latest Albian or earliest Cenomanian (Austin, Schlager, et al., 1986).

The Late Cretaceous-Paleogene deep-water sequence is one of the most important features of Great Isaac, one that distinguishes this well from the other Bahamian deep tests at Cay Sal, Andros, and Long Island, where shallow-marine environments prevailed throughout (Meyerhoff and Hatten, 1974). However, the sequence has a parallel in the Pine Key Formation of southern Florida (Maher, 1965; Winston, 1971; Meyerhoff and Hatten, 1974). For Great Isaac, the interpretation as deeper water deposits is based on the abundance of calcareous plankton in the form of planktonic foraminifers, calcispheres, and nannofossils. In the Senonian sequence, plankton accounts for $80 \%$ -
$90 \%$ of all biota, and unquestionably neritic benthos are scarce. About $50 \%-80 \%$ of the cuttings contain only planktonic remains. In a low-latitude setting such as the Bahamas, this is an indication of deposition below the euphotic zone, because of ample proof of prolific benthic carbonate production in the euphotic zone at this time in the nearby wells of Cay Sal (Greta Mackenzie, unpubl. observations) and Andros (Goodell and Garman, 1969). We are reluctant to extend the same line of reasoning to the higher latitude shelves of the Cretaceous where plankton may have dominated even where the seabed reached the euphotic zone (e.g., Kennedy and Garrison, 1975, p. 320).

Independent evidence of deep-water conditions in this inter$\mathrm{val}$ is derived from comparison of accumulation rates in Bahamian wells. The accumulation curves of Great Isaac and Cay Sal IV, nearly parallel in the Late Jurassic and Early Cretaceous, diverge from the time of drowning at Great Isaac until the base of the Oligocene, when they converge again (Fig. 3). If one assumes that Cay Sal IV remained at sea level and recorded the overall subsidence of the area, then the maximum water depth at Great Isaac, reached in the latest Eocene, was about $660 \mathrm{~m}$. Since this time, water depth has decreased to zero as the prograding platform filled the basin.

It remains unclear where in the uppermost section of Great Isaac the transition from upper slope to platform occurs, as there are no cuttings from the top $200 \mathrm{~m}$. Currently, the site is on the platform margin, and the material at $200 \mathrm{~m}$ is interpreted as slope deposits because of both occurrence of sparse planktonic foraminifers and clinoform geometry in seismic profiles (see section on seismic profiles). Increasing numbers of plank- 


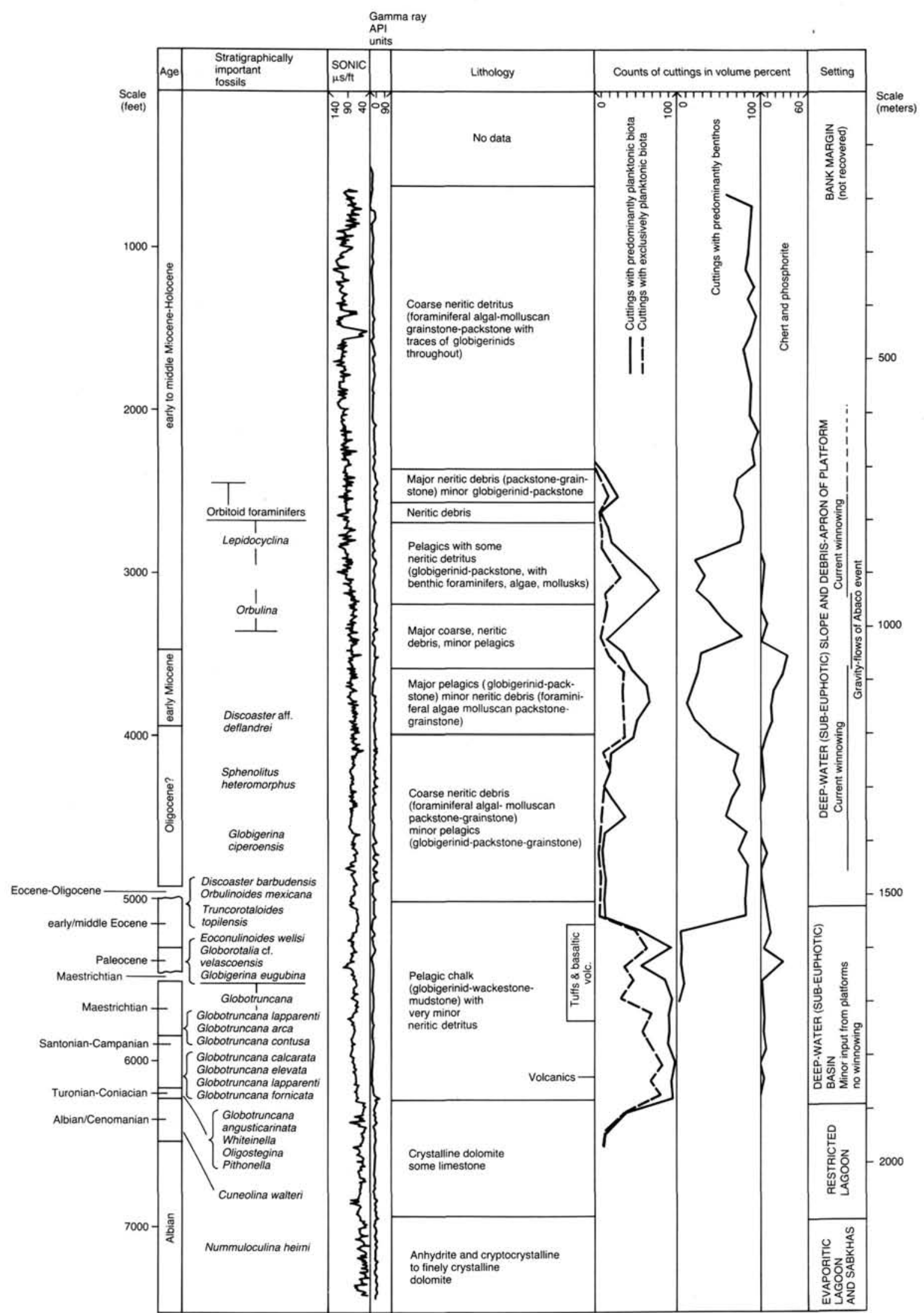

Figure 2. Well log of Great Isaac, showing, from left to right: stratigraphic stages; important microfossils; gamma ray and sonic log; lithologic units; percentages of plankton, benthos, and chert in thin sections; depositional setting. 

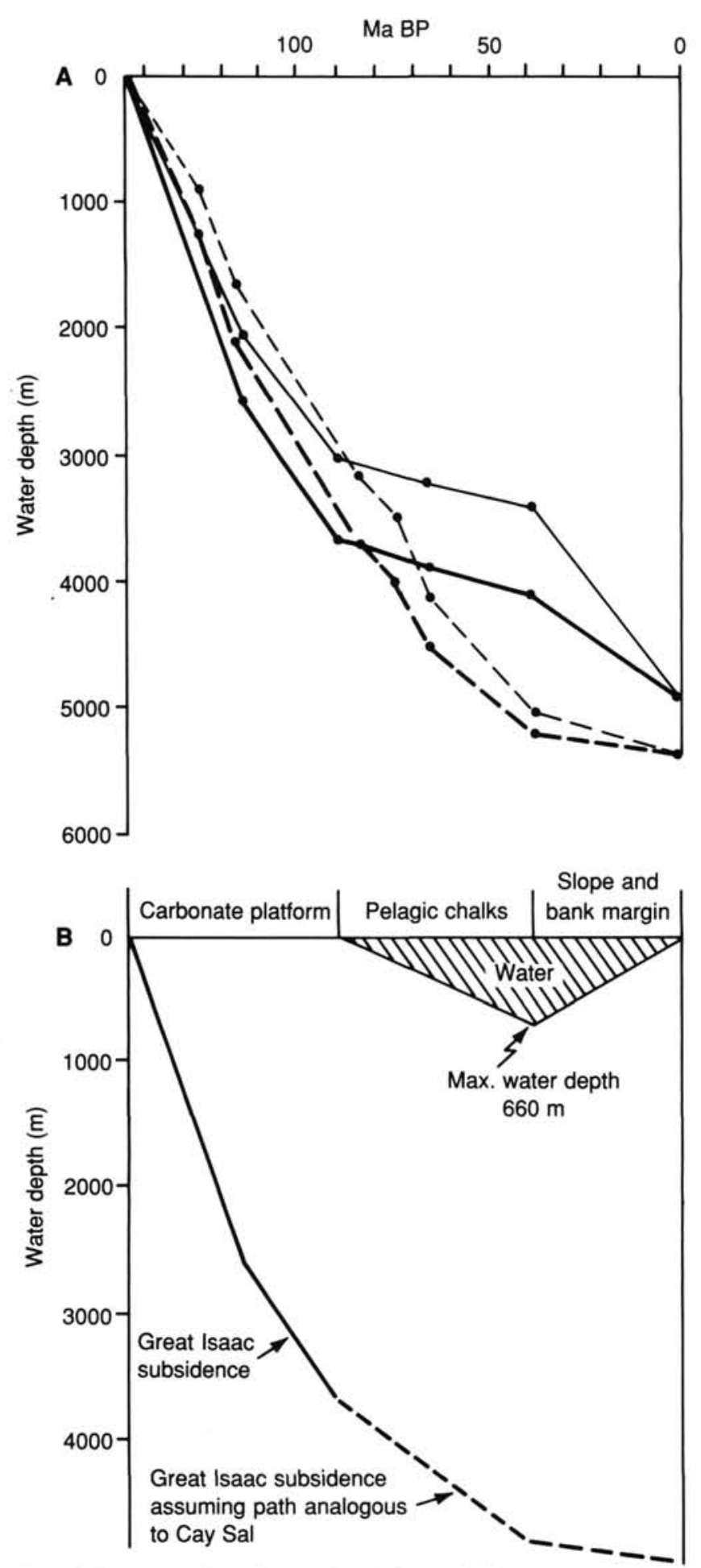

Figure 3. Reconstruction of water depth from subsidence curves of Great Isaac (solid lines) and Cay Sal (dashed lines) wells (based on unpublished observations by F. Bourgeois and E. Fluegel). A. Thin lines: uncorrected subsidence (Cretaceous-Holocene) of both wells; heavy lines: compaction-corrected subsidence (compaction curve of Schmoker and Halley, 1982). Note anomalous S-shape of Great Isaac curve. B. Restoration of Great Isaac curve assuming that well site subsided parallel to Cay Sal, where platform sequence is continuous. This restoration suggests that, during deposition of pelagic chalks, water depths at Great Isaac reached $660 \mathrm{~m}$, subsequently reduced to near zero by progradation of Bahama Bank. tonic foraminifers below $360 \mathrm{~m}$, along with evidence on seismic profiles of prograding clinoforms in this interval, indicate definite slope environments downward of $360 \mathrm{mbsf}$.

Also questionable is the boundary between the slope and the debris apron at the basin margin. Modern Bahamian slopes show a pronounced decrease in declivity at this point, along with a change in facies from predominantly muddy slope deposits to turbidite-rich apron deposits (Schlager and Chermak, 1979; Mullins et al., 1984; Austin, Schlager, et al., 1986). We were unable to recognize such a boundary, perhaps because the slope mud was unlithified and thus washed away by the drill or because current-winnowing prevented slope muds from accumulating in the Florida Straits.

Vesicular lavas and tuffs make up more than $50 \%$ of some samples in the 5200-5750 ft interval (Late Cretaceous to Eocene) in Great Isaac 1. This volcanism may be related to the collision of the Cuban island arc with the Bahamas at about that time (Angstadt et al., 1985).

\section{Correlation of Great Isaac and Site $\mathbf{6 2 6}$}

Ties between Great Isaac and nearby Site 626 in the Florida Straits are provided by the Neogene biostratigraphy, a lithostratigraphic marker, and seismic reflectors. The lower/middle Miocene boundary and the Oligocene/Miocene boundary can be correlated through biostratigraphy. In this interval, deepwater conditions prevailed at both sites, and nannoplankton, planktonic foraminifers, and some benthic foraminifers were used for age determinations. Figure 4 shows that the stratigraphic uncertainties in Great Isaac are greater by a factor of 5 to 10 , probably owing to "smearing" inherent in analysis of cuttings. However, the well-defined boundaries of Site 626 fall within the error bar of Great Isaac, suggesting near-horizontal time lines between the two sites.

The debris flows of the Abaco event at Site 626 (Austin, Schlager, et al., 1986; Fulthorpe and Melillo, this vol.) are tentatively identified at Great Isaac as an interval of particularly coarse and abundant neritic lithoclasts at almost exactly the same depths (Fig. 5). We attribute the concomitant increase in gamma-ray response to the presence of fine clay-bearing sediment. Site 626 shows that the perennial sediment at this time is almost completely winnowed and devoid of fines. Only the Abaco debris flows contain fines in their matrix. Correlation of debris flows and biostratigraphic markers suggests strongly that both sites were in a deep-water environment at that time and also very nearly at the same water depth (Fig. 4).

\section{Seismic Profiles and Borehole Stratigraphy}

We have examined the top $1.8 \mathrm{~s}$ of lines $7-\mathrm{N}$ and $5 \mathrm{~A}-\mathrm{N}$ of a 1982 industry survey. These lines were also included in the seismic interpretation by Eberli and Ginsburg (1987). Line 7-N passes over the Great Isaac drill site (Fig. 6). Seismic reflections clearly show an upper, incoherent zone and a lower, layered one. The incoherent zone corresponds to the coarse neritic debris of slope and bank margin, and the layered section represents the pelagic-chalk-and-debris sequences and the carbonate-evaporite lithologies of the Cretaceous platform.

Details of the correlation between line 7- $\mathrm{N}$ and borehole stratigraphy are presented in Figures 6 and 7. The incoherent reflections between seafloor and reflector 1 represent coarse platform detritus, interpreted as deposits of bank margin, slope, and proximal apron. The discontinuous, weak reflections between reflectors 1 and 2 correlate with fine neritic debris and pelagics, interpreted as distal apron sediments. Curved reflections in the middle of this unit are interpreted as slump tongues and debris flows of the Abaco event that lie within this unit and were prob- 


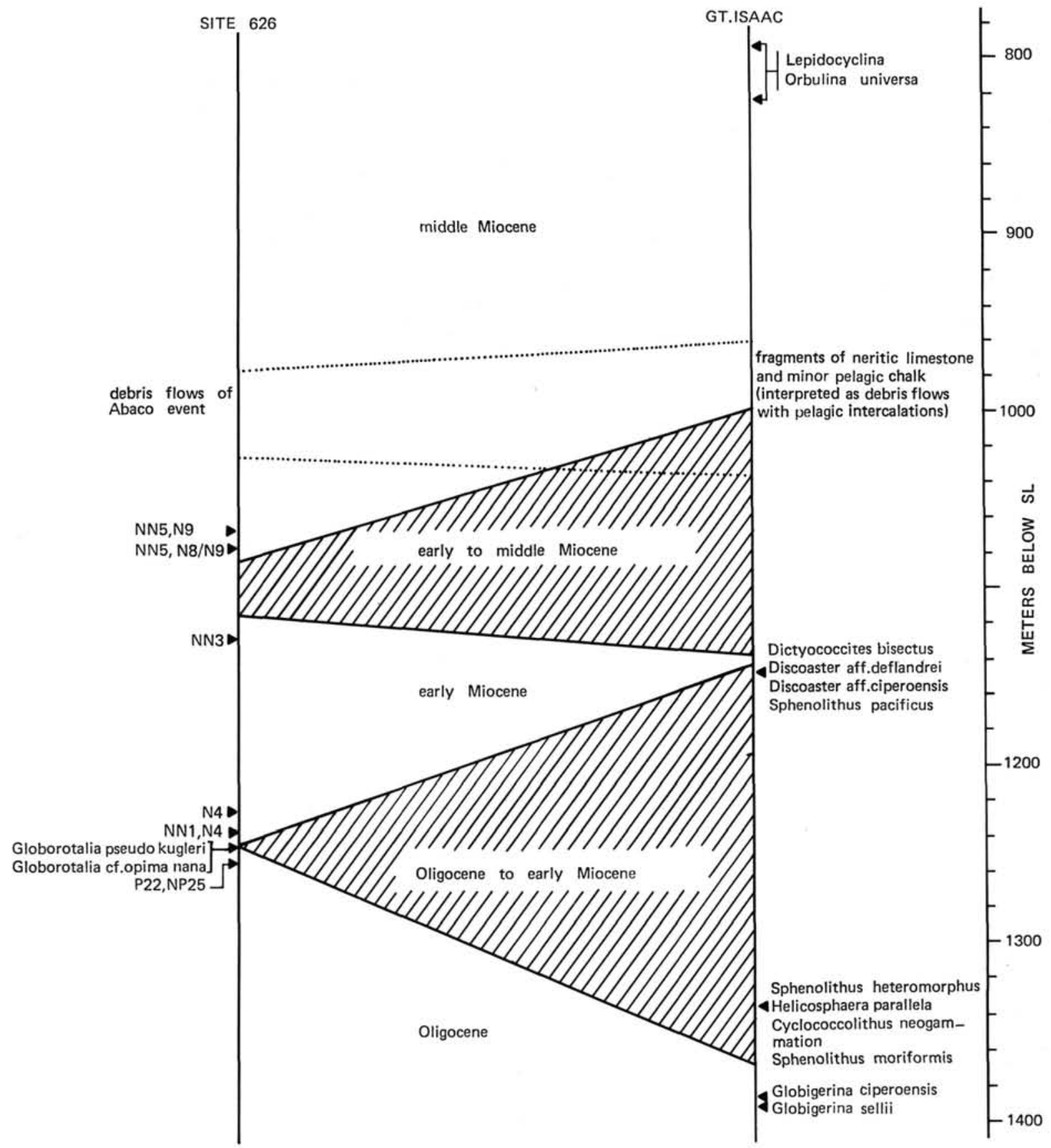

Figure 4. Stratigraphic correlation between Great Isaac and ODP Site 626. Biostratigraphy, and Abaco event as lithologic marker, indicate near-horizontal time lines between the two sites. Greater uncertainty of stratigraphy at Great Isaac results from lack of continuous cores. For identification of Abaco event, see Figure 5 and text.

ably imaged perpendicular to their transport direction. An interval of greatly varying thickness and diverging, high-amplitude reflections between reflectors 2 and 3 corresponds to an alternation of coarse neritic debris and pelagic chalks, interpreted as a tongue of proximal apron deposits. The interval between reflectors 3 and 4 shows even thickness and rather parallel reflections of generally low amplitude. This unit corresponds to pelagic chalks that seem to form a drape over the drowned platform. Discontinuous reflector $3^{\prime}$ within this sequence marks a latest Cretaceous hiatus.

The high-amplitude, continuous reflector 4 is interpreted as the top of the Cretaceous platform. Since this horizon represents a drastic change in environment, widely quoted as a marker in seismic stratigraphy, we present our arguments for this correlation in more detail than for the other reflectors.

At Great Isaac 1, the boundary is identifiable as a pronounced kick on sonic and formation density logs at $1893 \mathrm{~m}$ below derrick floor (i.e., $1871 \mathrm{~m}$ below sea level) (Fig. 8). Seismic reflector 4 lies at $1.17 \mathrm{~s}$ twt (two-way traveltime) on line $7-\mathrm{N}$ at the drill site, which converts to $1866 \mathrm{~m}$ with Dix average and interval velocities (Fig. 7) and to $1840 \mathrm{~m}$ with root-mean-square velocities. Furthermore, we have converted the depth-in-hole of the platform top to traveltime, using 26 visually estimated averages of the sonic log and the interval velocity on line $7-\mathrm{N}$ for the (unrecorded) top $500 \mathrm{ft}$. This yields a position of $1.13 \mathrm{~s} \mathrm{twt}$ for the boundary, $0.05 \mathrm{~s}$ above reflector 4 . Lastly, seismic interval 


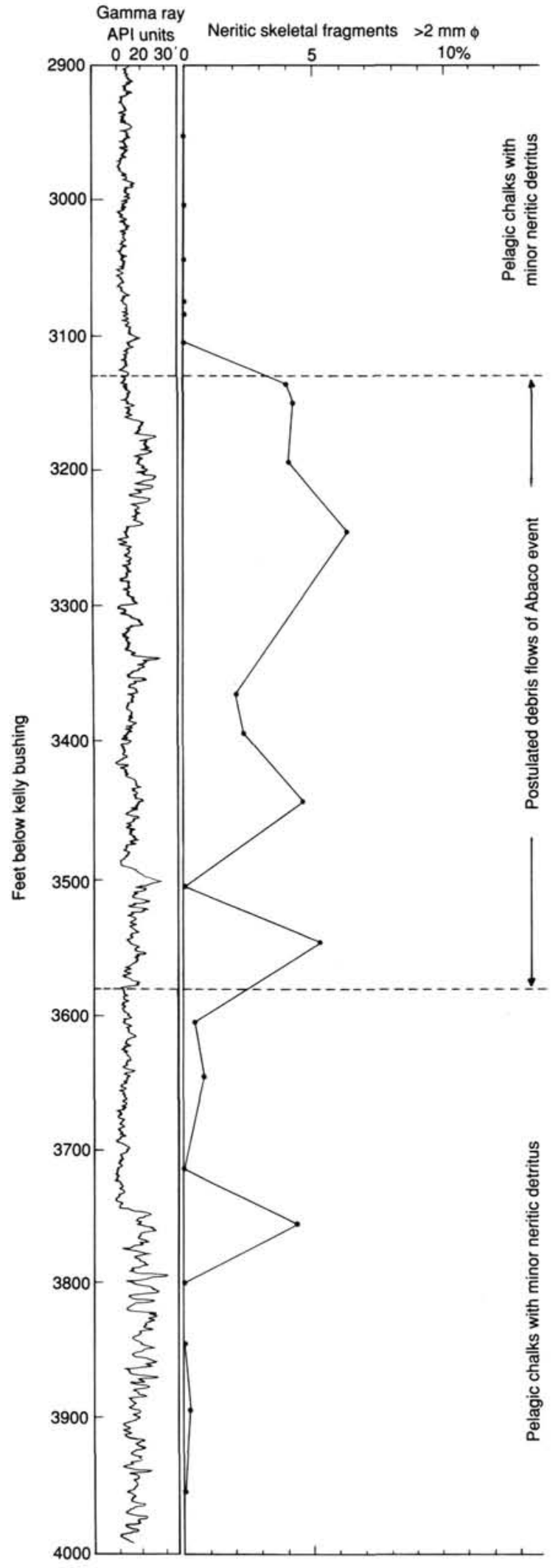

Figure 5. Abaco event (tectonically triggered gravity flows) in Great Isaac: event is indicated by drastic increase of coarse skeletal material (clasts in debris flows) and by increase in natural gamma radiation, attributed to clay-bearing fines in the matrix of gravity flows. See text for further discussion. velocities indicate a change at $1.1 \mathrm{~s}$ from 3.7 to $4.7 \mathrm{~km} / \mathrm{s}$, comparable to the change at the platform top in the hole from 3.84.0 to $5.3 \mathrm{~km} / \mathrm{s}$. We consider all these estimates to be in sufficiently good agreement to firmly identify reflector 4 as the top of the Cretaceous platform.

The top of the evaporite-bearing sequence that lies about 200 $\mathrm{m}$ below the platform top may appear as the semicontinuous reflector $4^{\prime}$ on line $7-\mathrm{N}$, but the reflector is barely visible in the vicinity of Great Isaac 1. The high-amplitude reflections below $1.3 \mathrm{~s}$ can be confidently correlated with the carbonate-anhydrite alternations observed deeper in the hole. The seismic character is very similar to that of sequence $\mathrm{G}$ on the southern Blake Plateau, where ODP Site 627 revealed the presence of a carbonateevaporite facies (Austin et al., this vol.).

Line $5 \mathrm{~A}$ crosses the margin of Great Bahama Bank southwest of Great Isaac 1 (Fig. 9). It significantly amplifies the stratigraphy sketched above for line 7-N. Most of what appears as incoherent returns on line 7-N shows basinward-dipping reflections on line $5 \mathrm{~A}$ and is interpreted as a prograding platform slope with maximum dips of about $10^{\circ}$. The clinoforms are within $0.05 \mathrm{~s}$ below seafloor. The true platform deposits are therefore only $50 \mathrm{~m}$ thick at the margin. This implies that the Great Isaac area must have been incorporated into the Bahama Bank not earlier that the Pliocene, about 3-5 Ma (see Williams, 1986, for bank stratigraphy and subsidence rates in this interval). This conclusion agrees with observations by Eberli and Ginsburg (1987). The transition in the borehole between upper slope and bank-margin deposits must lie in the nonrecovered interval of the top $200 \mathrm{~m}$. The height of the prograding clinoforms in the Neogene section of Figure 9 is $250-300$ m, assuming velocities of $2000 \mathrm{~m} / \mathrm{s}$ for the deep-water sediments and $2500 \mathrm{~m} / \mathrm{s}$ for the young platform deposits.

All numbered reflectors of line 7-N can be traced on line 5A-N; however, they have different significance. Reflector $1^{\prime}$, discontinuous and hardly traceable on line $7-\mathrm{N}$, is a sequence boundary on line $5 \mathrm{~A}-\mathrm{N}$, separating seafloor-parallel reflections above from westward-dipping reflections below. Reflector 1 lies within the westward-dipping unit. Reflectors 2 and 3 form the upper and lower boundaries, respectively, of a westward-thinning sequence. The same unit also thins to the northeast on line $7-\mathrm{N}$. It represents a tongue of debris shed from a platform located to the southeast.

Reflector 3 is the most prominent sequence boundary, separating a lower unit of low-amplitude, parallel reflections, and even thickness from high-amplitude diverging reflections above. The lower unit represents pelagic chalks, and the upper system represents the first debris lobes of the prograding Tertiary platform.

Reflector 4 is also a major boundary, and it coincides with the top of the Cretaceous platform at Great Isaac. On line 5A$\mathrm{N}$, the reflector can be traced clearly across the present bank margin and the slope. Under the Florida Straits the reflector is often weak, whereas the event $0.08 \mathrm{~s}$ below it, probably the top of the anhydritic section, stands out prominently. The reason for the local weakness of the platform-top reflection is unclear. The low-velocity layers $30-100 \mathrm{~m}$ deeper in the section provide one possible explanation (Fig. 8). Minor changes in spacing of these events may lead to destructive interference that weakens all reflections from this interval. The double-event character of the reflector is clearly visible in both lines. Another possibility is lateral change in properties. Sonic and formation-density logs show the top $100-120 \mathrm{~m}$ of platform rocks to be particularly fast and dense. Velocity and density values $150-210 \mathrm{~m}$ below the top drop to values very similar to those of the overlying chalk. Chalkification, evaporite leaching, or other local diagenesis may be responsible for this. The reflector at the platform top would 

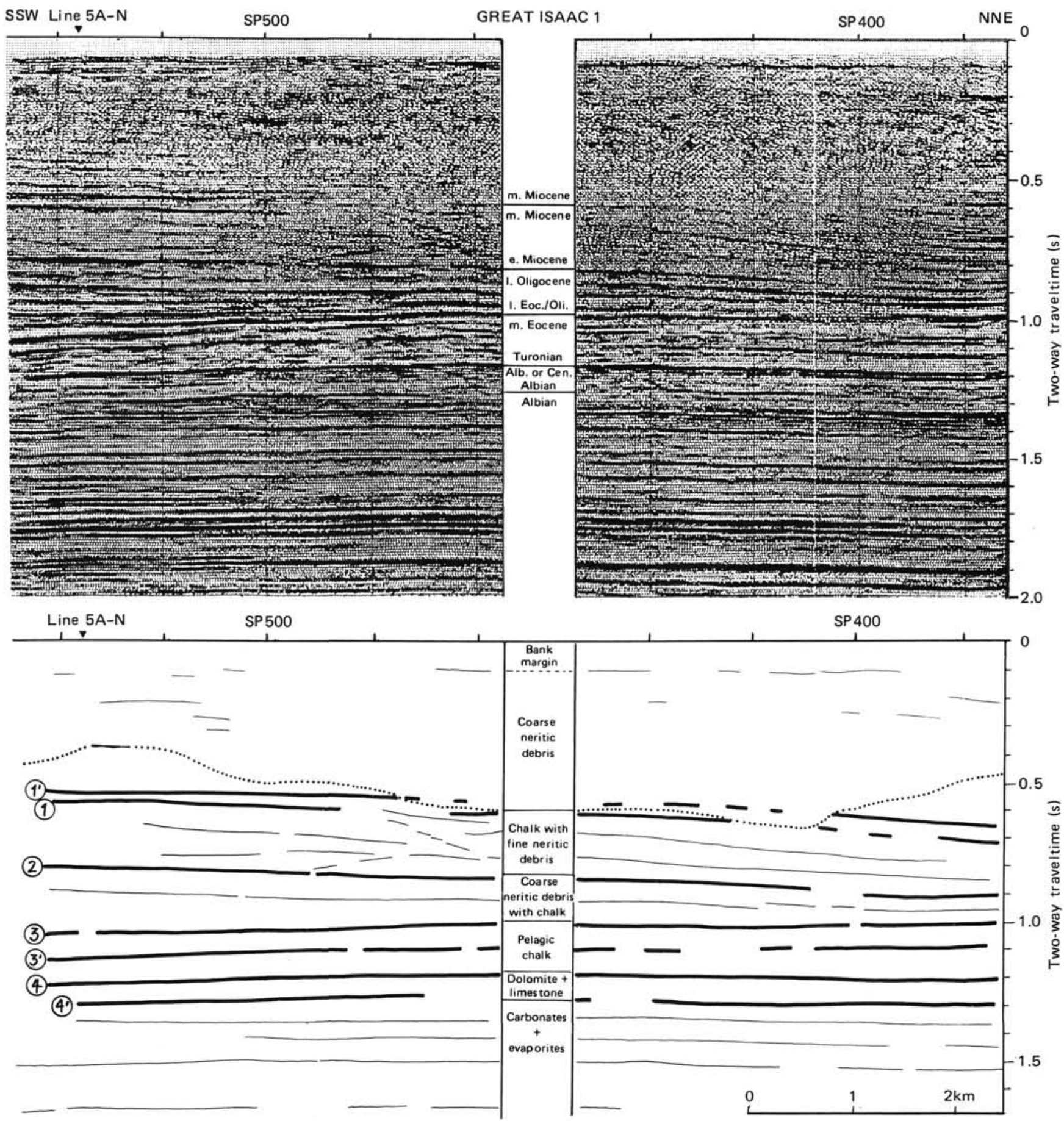

Figure 6. Seismic line 7-N and borehole stratigraphy of Great Isaac (see Fig. 1 for location). Circled numbers refer to reflectors traced to line 5AN. Dotted line delimits diachronous boundary of incoherent slope facies. Line cuts across lobe of Great Bahama Bank so that well represents innermost position on bank with thickest development of proximal slope facies. Left and right ends of line approach present bank margin where only upper section is developed as proximal slope facies.

disappear where the low-velocity, low-density dolomite comes in contact with the chalk. A third interpretation involves a facies change from a small shelf atoll to deeper water deposits around it (Austin et al., this vol.). In this case, the evaporite-bearing sequence would mark the top of the continuous platform (see discussion section).

\section{DISCUSSION}

\section{Validity and Resolution of Stratigraphic Column}

The fact that our observations are based primarily on cuttings with few sidewall cores and only two full cores poses definite limitations on stratigraphic and sedimentologic interpreta- 


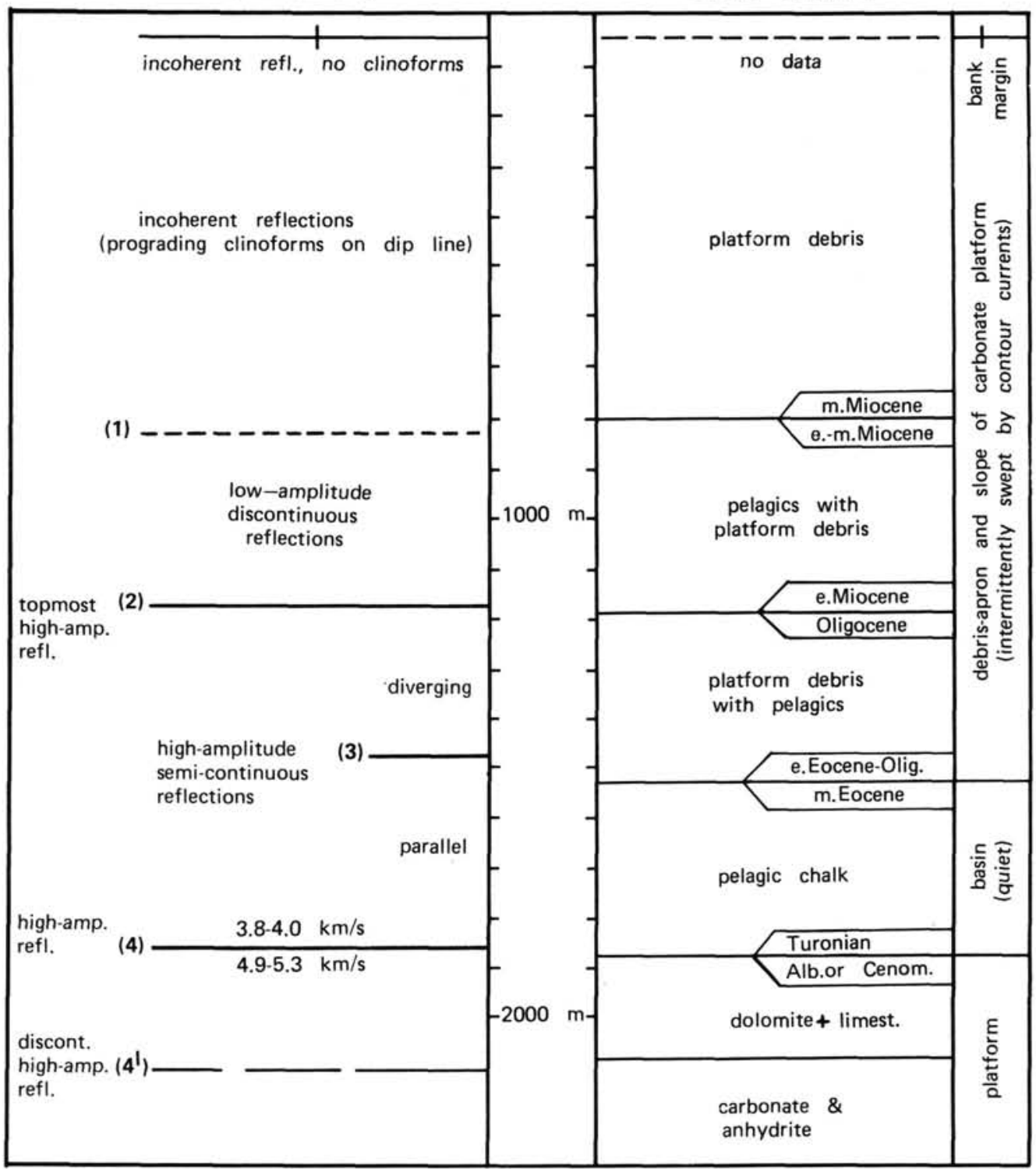

Figure 7. Comparison of seismic reflection character and lithology at Great Isaac well. Depth of seismic reflectors was calculated with Dix average and interval velocities. Ages in left column refer to sediments immediately above and below boundary.

tions. We feel strongly, however, that the main features of the sequence are clearly identifiable, as occasional controls from independent lines of evidence confirm. Among these controls are (1) correlation of changes in seismic reflection character with changes in facies and log readings observed in the borehole (Fig. 7); (2) similarity of the succession at the Cretaceous platform top in the continuously cored ODP Site 627 with the one reconstructed from cuttings in Great Isaac; and (3) recognition of an interval of particularly coarse platform debris (interpreted in 1971 as cavings) exactly at the elevation of the Abaco event (debris flows) at Site 626 in the Florida Straits.

Sedimentologically, the cuttings technique eliminates all criteria diagnostic of bedding and small-scale distribution of lithologies. Another complication is loss of unlithified sediments. For instance, it is unclear whether the platform debris in the top $500 \mathrm{~m}$ is the representative lithology or if these fragments form layers of clasts in muddy slope sediments that were washed away. In addition, all boundaries, even the sharp ones, are blurred over $50-200 \mathrm{~m}$. This is indicated by downhole extension of pelagic chalks into the unit of platform dolomites, scattering of volcanics, and discrepancies between sidewall cores and composition of cuttings near lithologic boundaries (such as near 1500 $\mathrm{m}$ in the hole).

\section{Evidence of Deep-water Conditions at Great Isaac}

Discovery of a Late Cretaceous-Paleogene deep-water sequence beneath Great Bahama bank is one of the most important stratigraphic results from the Great Isaac well. Arguments for this interpretation were presented in the "Results" section; we evaluate them here in a broader context.

Pervasive occurrence of planktonic fossils in the Upper Cretaceous and Paleogene section, notably the abundance of cuttings with only planktonic remains, indicates deposition below the euphotic zone (i.e., at more than 50-100 m water depth). 


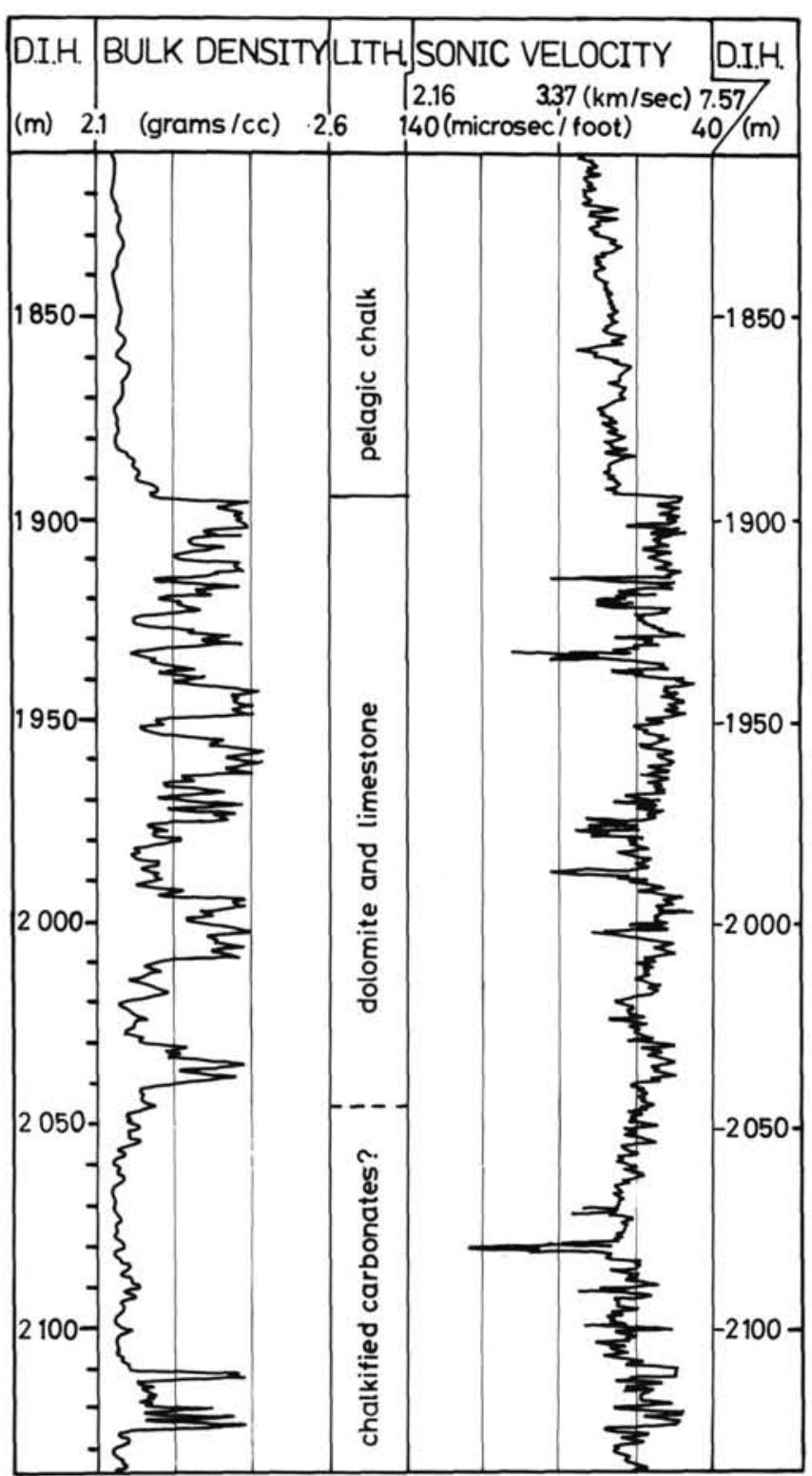

Figure 8. Lithology, bulk density, and sonic velocity of the interval $1800-2140 \mathrm{~m}$, showing upper part of Cretaceous platform and overlying pelagic chalk. Column D.I.H. (depth-in-hole) displays depth from derrick floor in meters. Note sharp increase of density and velocity at platform/chalk boundary; $150 \mathrm{~m}$ below the platform top, density and velocity decrease to values similar to chalk. The intermittent disappearance of the platform-top reflector in Figure 9 may indicate areas where the low-density/low-velocity carbonates directly underlie the chalks. The unusually low properties of the bank carbonates are attributable to diagenetic alterations such as chalkification (leaching) of carbonate and dissolution of anhydrite. Boundaries of basin slope and platform areas refer to present-day configuration.

This estimate is further constrained to water depths of about $600 \mathrm{~m}$ by comparison of the accumulation curves of Great Isaac-1 and well Cay Sal-IV that shows shallow-water deposits throughout (Fig. 3). Progradation geometry on seismic profile $7-\mathrm{N}$ (Fig. 9) indicates minimum water depths of $250-300 \mathrm{~m}$ in the Neogene, at a time when water depths were shoaling again as the prograding flank of the platform approached the Great Isaac drill site. Using porosity logs and subsidence curves of other wells for comparsion, Williams et al. (this vol.) also pos- tulate deep-water conditions followed by an upward-shoalingslope-to-platform sequence for Great Isaac. We believe that the interpretation of the Great Isaac sequence as a succession of platform, basin, and platform is indeed inescapable.

\section{Seismic Stratigraphy of the Bahamas}

Recently, several important seismic studies have been conducted in the northwestern Bahamas. With the material available to us, we cannot directly correlate our study with them but must jump-correlate. In Table 1 we summarize the outcome of these speculations. Specific comments follow below.

The most extensive study, which integrates the data of Sheridan et al. (1981), is by Ladd and Sheridan (1987). A sequence of seismic units and marker reflectors was traced through Exuma Sound, Tongue of the Ocean, and the Providence Channels into the Straits of Florida. Ladd and Sheridan's stratigraphy can be linked to ours through a comparison of reflection character and travel times in the Florida Straits. In their profiles, we clearly recognize the low-amplitude interval of pelagic chalks, sandwiched between the high-amplitude reflections of the Cretaceous platform below and the debris tongues above. Consequently, we correlate their reflector $P$ with either our reflector 4 or $4^{\prime}$. Discriminating between these two alternatives is very difficult because either reflector may disappear locally, as shown on Figures 6 and 9. Reflector R of Ladd and Sheridan forms the upper boundary of the low-amplitude zone and is thus equivalent to our reflector 3. Ladd and Sheridan (1987) report prograding platform slopes in some places above reflector $\mathrm{R}$, in agreement with the first appearance of coarse platform debris in the same position in Great Isaac. A correlation of reflector $\mathbf{R}$ with reflector 3 at Great Isaac implies a mid-Eocene age for this seismic horizon, whereas Ladd and Sheridan assign reflector $\mathbf{R}$ to the Santonian-Coniacian or the Cretaceous/Tertiary boundary.

Austin et al. (this vol.) report on the grid survey of Site 626 in the Florida Straits. They present the most detailed stratigraphy with a much higher resolution than ours. However, the overall reflection character and interval thicknesses are very similar to those of line 5A-N. The correlation shown in Table 1 implies that our reflector $3^{\prime}$, the top-Cretaceous hiatus, was not recognized as a sequence boundary by Austin et al. (this vol.). This is understandable, considering the discontinuous nature of the reflector and the lack of distinct changes in bedding geometry at this horizon. Sequence boundary $0 / 1$ of Austin et al. (this vol.) corresponds to either reflector 4 or $4^{\prime}$. The problem of discriminating between these alternatives is analogous to the ambiguity in correlating reflector P of Ladd and Sheridan (1987) because the base of sequence 1 of Austin et al. is identical with reflector P of Ladd and Sheridan.

Eberli and Ginsburg (1987) present lines from Great Bahama Bank. Correlation of our borehole data with their seismic stratigraphy is hampered by seismically incoherent zones under parts of Great Bahama Bank and thus is most tenuous. We follow the suggestion of these authors and identify their "lower correlation (C) horizon" with the top of the Cretaceous platform. Their "upper correlation (C) horizon" was indeed, as they surmise, a Tertiary event, as the Upper Cretaceous sequence is purely pelagic and therefore very thin in the area.

\section{Paleogeography of Northwestern Bahamas}

ODP Leg 101 addressed, among other topics, the megabank vs. graben hypothesis of the origin of platforms and basins in the Bahamas (see Talwani et al., 1960, and Mullins and Lynts, 1977, for the graben hypothesis; Meyerhoff and Hatten, 1974, Sheridan et al., 1981, and Schlager and Ginsburg, 1981, for the megabank hypothesis). 


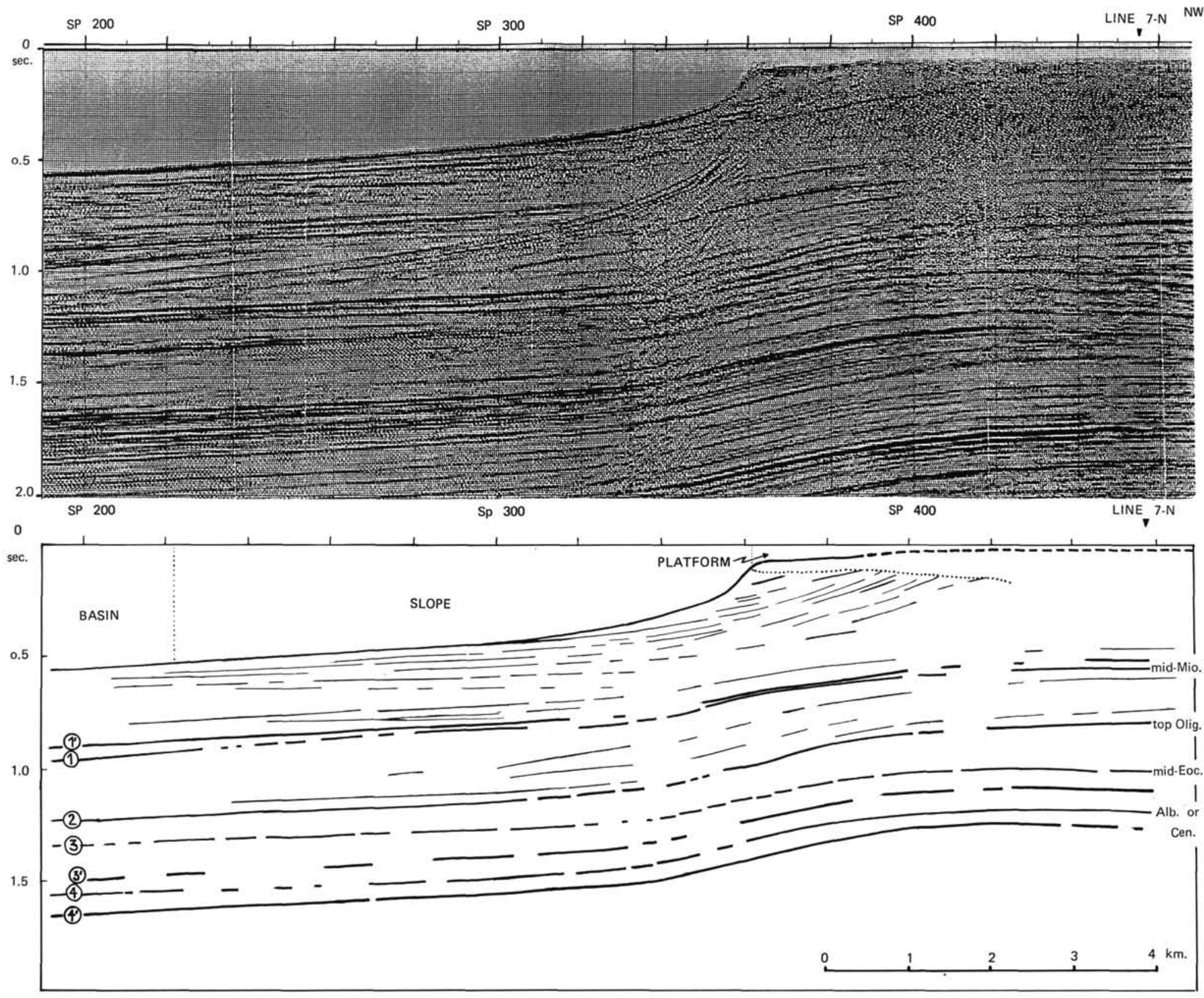

Figure 9. Seismic line 5A-N, crossing bank margin southwest of Great Isaac (see Fig. 1). Circled numbers indicate reflectors identified on line 7-N. Basin, slope, and platform environments are separated according to present-day topography; boundary between basin and slope is drawn at a slope tangent of $0.025\left(1.4^{\circ}\right)$ and marked by a dotted line. 
Table 1. Correlation of seismic reflectors and sequence boundaries in the northwestern Bahamas.

\begin{tabular}{|c|c|c|c|}
\hline $\begin{array}{l}\text { Ladd and Sheridan } \\
\text { (1987) }\end{array}$ & $\begin{array}{l}\text { Austin et al. } \\
\text { (this vol.) }\end{array}$ & This study & $\begin{array}{l}\text { Eberli and Ginsburg } \\
\text { (1987) }\end{array}$ \\
\hline Reflectors and proposed age & Sequence boundaries & Reflectors and age & Reflectors and age \\
\hline- & $9 / 10$ & 1 middle Miocene & - \\
\hline- & - & $1^{\prime}$ middle Miocene & - \\
\hline $\mathrm{O}$ early/middle Miocene & - & - & - \\
\hline- & $5 / 6$ & 2 top Oligocene & upper c horizon? \\
\hline $\begin{array}{l}\text { R Santonian/Coniacian or } \\
\text { Maestrichtian/Paleo- } \\
\text { cene }\end{array}$ & $1 / 2$ & 3 middle Eocene & - \\
\hline- & - & $3^{\prime}$ top Cretaceous & - \\
\hline P? Albian/Cenomanian & $0 / 1 ?$ & 4 Albian or Cenomanian & lower $\mathrm{c}$ horizon? \\
\hline P? & $0 / 1 ?$ & $4^{\prime}$ Albian & lower $\mathrm{c}$ horizon? \\
\hline
\end{tabular}

Leg 101, the examination of Great Isaac and Cay Sal IV boreholes, and the recent seismic surveys of the Bahama Banks (Ladd and Sheridan, 1987; Eberli and Ginsburg, 1987; Austin et al., this vol.) have all added important observations to this discussion. Most of them strengthen the megabank hypothesis, as discussed below.

1. Comparison of Site 626 and Great Isaac indicates nearly horizontal time lines and very similar deep-water facies in the Oligocene-Miocene interval of the two wells. There is no indication of either depositional relief or fault scarps at that time, and the present location of the bank margin in this area has to be the result of slope progradation during the Neogene.

2. Stratigraphic ties between Sites 626 and Great Isaac suggest that the top of the Cretaceous platform cored in Great Isaac corresponds to reflector $\mathrm{P}$ beneath the Florida Straits (Austin, Schlager, et al., 1986). This reflector has been interpreted on seismostratigraphic grounds as the top of a drowned platform, i.e., velocity increases from 2.9 to nearly $5 \mathrm{~km} / \mathrm{s}$ and a highly reverberatory lower unit (Austin et al., this vol.). The reflector has up to $200 \mathrm{~m}$ relief, because of atoll-like features that rise above the continuous platform reflector. The elevation of the high parts of the platform-top reflector corresponds almost exactly to the platform/chalk boundary in Great Isaac (Fig. 10). We suggest that the evaporite-free carbonates at 1890 $2090 \mathrm{~m}$ in Great Isaac represent one of these shelf atolls and that the evaporite-bearing sequence below $2090 \mathrm{~m}$ represents the top of the restricted platform interior facies of the megabank. The mid-Cretaceous platform/chalk boundary extends westward to southern Florida (Meyerhoff and Hatten, 1974; Winston, 1971). This regional pattern suggests that the northern Straits of Florida, the northwestern Bahamas, and parts of Florida are all underlain by the same Cretaceous carbonate platform, and that proto-Straits were established when this vast platform was partly drowned in the mid-Cretaceous.

3. Drilling at Site 627 established that the southern Blake Plateau is also underlain by this Cretaceous platform and it too was drowned in the mid-Cretaceous.

4. Occurrence of detrital quartz in the Cretaceous platform dolomites of Great Isaac and absence of terrigenous material in the Neogene Bahama Banks suggest that, unlike the modern Bahamas, the Cretaceous platform was attached to a land mass.

5. Recent high-quality seismic data, as well as the stratigraphy of Great Isaac, document the migration of bank margins with time. At Great Isaac, stratigraphy records platform retreat in the mid-Cretaceous and reoccupation of this position by the prograding bank margin in the Neogene. This interpretation was proposed by one of us (F. B.) as early as 1971. The seismic profiles corroborate this inference and document platform progradation of tens of kilometers for the leeward bank margins in the northwestern Bahamas (Eberli and Ginsburg, 1987). Leg 101 indicates margin mobility also in other parts of the northern Bahamas (Austin, Schlager, et al., 1986). In the Bahamas, much like many ancient platforms, advancing and retreating bank margins seem to be a common feature. This mobility of bank margins, along with their demonstrated ability to fill basins and level tectonic relief (their "healing power"), makes it unlikely that tectonic features of Jurassic age have much control on the present-day pattern of platforms and troughs.

We conclude that the present pattern of platforms and basins in the area is satisfactorily explained by the megabank hypothesis, with the modification that platforms not only shrank but also reexpanded.

\section{Gulf Stream History}

At Site 626, almost the entire section (upper Oligocene-Holocene) consisted of winnowed skeletal sands with mostly planktonic and some minor neritic benthic material. This sediment was interpreted as contourites (i.e., the residue of an alternation of pelagic sediment with neritic turbidites) where most of the fines have been carried away by the Gulf Stream. Great Isaac shows a similar facies in the Tertiary: planktonic foraminifers occur mostly in packstones and even in clean grainstones. We found no plankton-bearing mudstones and only few wackestones in the Tertiary deposits. We conclude that during the Tertiary, Great Isaac was winnowed by contour currents in much the same way as Site 626 in the present Straits of Florida. In the Cretaceous, the facies is distinctly different. Plankton-bearing mudstones and wackestones are common, whereas planktonrich packstones and grainstones are nearly absent in the cuttings. The facies changes at the base or within the condensed section between the Maestrichtian and the middle Eocene horizons. The first evidence of bottom winnowing in the Eocene coincides with abundant tuff deposits. It is tempting to relate both volcanism and onset of Gulf Stream circulation to the arrival of the Cuban island arc that completed its collision with the Florida-Bahama block at about this time (Angstadt et al., 1985, p. 989). The first effect of the Gulf Stream may have been the formation of hiatuses on top of the Cretaceous sequence, so that now the Maestrichtian and mid-Eocene are only $50 \mathrm{~m}$ apart in Great Isaac. Our conclusions about the first appearance of Gulf Stream circulation agree well with those of Pinet and Popenoe (1985), derived from seismic surveys of the Blake Plateau.

\section{CONCLUSIONS}

1. According to seismic data and borehole stratigraphy, Great Isaac lay in the hypersaline interior of a carbonate platform in the Early Cretaceous, became part of a deep-water seaway when this platform was drowned in the Albian or Cenomanian, and 
SW

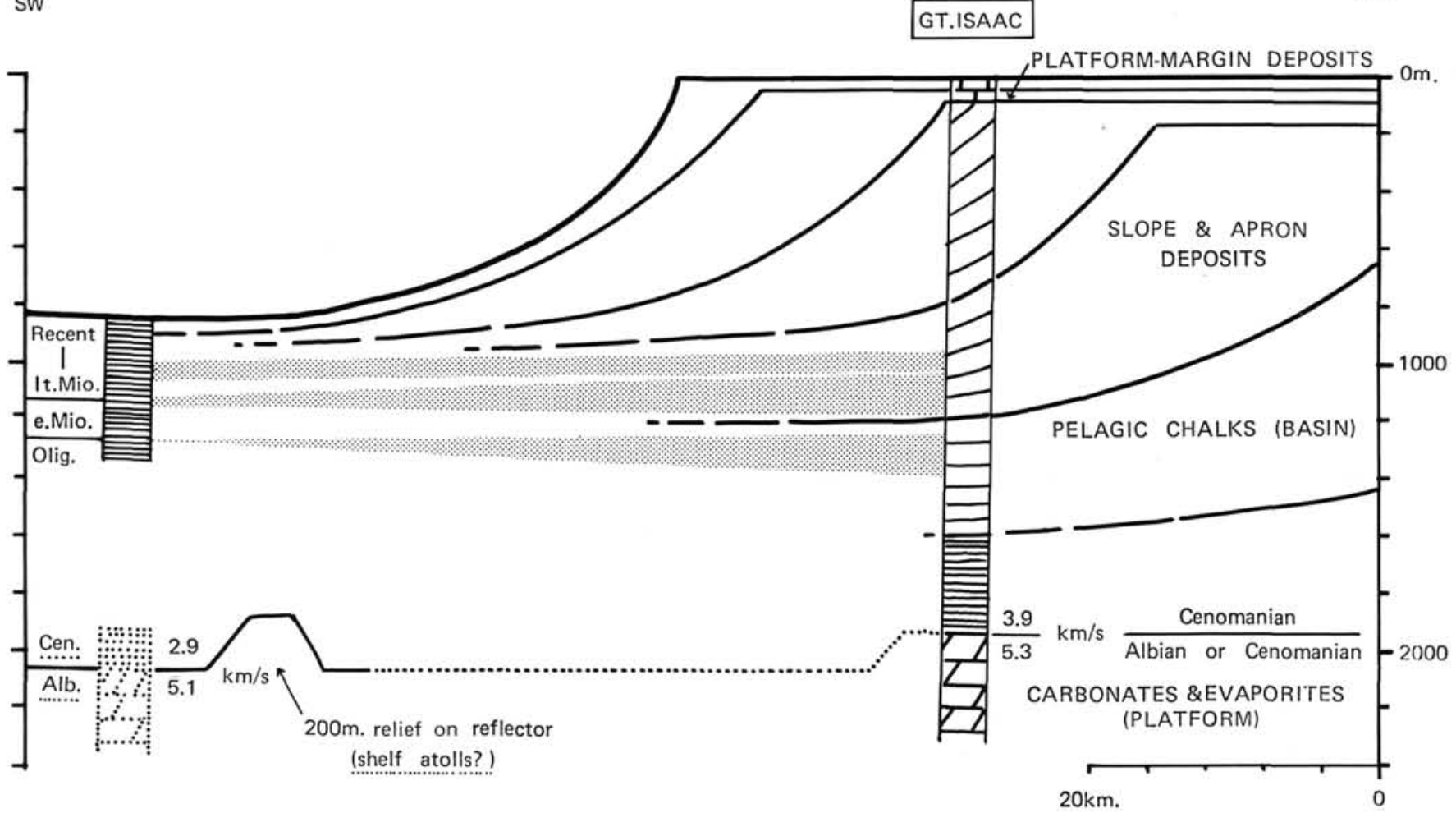

Figure 10. Major results of this report, presented in a schematic cross section from Great Isaac to ODP Site 626. Stippling represents stratigraphic ties between the two wells (see Fig. 4). Heavy lines show progradation of margin of Great Bahama Bank based on Great Isaac lithology and seismic profiles (see Figs. 6-9). Dotted lines indicate inferred correlation of drowned platform top in Great Isaac with reflector $P$ below Hole 626D in Florida Straits. Stratigraphic ties including correlation of platform top indicate near-horizontal time lines between the two wells in the Late Cretaceous and most of the Tertiary; present relief is caused by Neogene progradation and aggradation of the bank margin, aided by Gulf Stream erosion in the Straits of Florida.

was finally integrated into Great Bahama Bank when the prograding bank margin reached the site in the Neogene.

2. ODP Site 626 in the Florida Straits had a similar history, except that it has not yet been reached by the prograding margin of Great Bahama Bank.

3. The top of the Cretaceous platform at Great Isaac has the same elevation and nearly the same velocity profile as seismic reflector $\mathrm{P}$ at ODP Site 626 , confirming the interpretation of this reflector as the top of a drowned platform. Subhorizontal time lines between the Cretaceous and Tertiary sections of Great Isaac and ODP Site 626 argue against major tectonic structures beneath the present margin of Great Bahama Bank.

4. The mid-Cretaceous succession of shallow-water carbonates with evaporites and deep-water chalks is very similar in southern Florida, the Florida Straits, the Blake Plateau, and the western part of Great Bahama Bank. This suggests that the entire region formed a single vast platform in the Early Cretaceous. This platform was partially drowned in the mid-Cretaceous, but the surviving platform remnants reexpanded and reclaimed part of this territory during the Late Cretaceous and Tertiary.

5. Intensive winnowing of deep-water sediments at ODP Site 626 and Great Isaac since the Eocene supports the notion that Gulf Stream circulation started in the Early Tertiary, probably as the result of the collision of the Cuban island arc with its Florida-Bahamas foreland.

\section{ACKNOWLEDGMENTS}

We thank Chevron Overseas, Inc. (M.D.O. Lels and C. Jacobs) for providing material for this study and for permission to publish it. Texaco Latin America, Inc. (G. R. Bates), kindly released the seismic lines for publication. We are grateful to A. Chermak and G. Eberli for their advice on the seismics, R. de Jongh for point counts of plankton and benthos, and Harold Kaska for his help and advice in the early stages of this work. J. A. Austin, Jr., P. M. Harris, and A. A. Palmer reviewed the manuscript.

\section{REFERENCES}

Angstadt, D. M., Austin, J. A., Jr., and Buffler, R. T., 1985. Early Late Cretaceous to Holocene seismic stratigraphy and geologic history of southeastern Gulf of Mexico: AAPG Bull., 69:977-995.

Austin, J. A., Schlager, W., et al., 1986. Proc. ODP, Init. Repts., 101: College Station, TX (Ocean Drilling Program).

Eberli, G. P., and Ginsburg, R. N., 1987. Segmentation and coalescence of Cenozoic carbonate platforms, Northwestern Great Bahama Bank. Geology, 15:75-79.

Goodell, H. G., and Garman, R. K., 1969. Carbonate geochemistry of Superior deep test well, Andros Island, Bahamas. AAPG Bull., 53: 513.

Kennedy, W. J., and Garrison, R. E., 1975. Morphology and genesis of nodular chalks and hardgrounds in the Upper Cretaceous of southern England: Sedimentology, 22:311-386.

Ladd, J. W., and Sheridan, R. E., 1987. Seismic stratigraphy of the Bahamas. AAPG Bull., 71:719-736.

Maher, J. C., 1965. Correlation of subsurface Mesozoic and Cenozoic rocks along the Atlantic coast. AAPG Cross Sect. Publ., 3:1-18.

Meyerhoff, A. A., and Hatten, C. W., 1974. Bahamas salient of North America. In Burk, C. A., and Drake, C. L., (Eds.), The Geology of Continental Margins: New York (Springer-Verlag), 429-446.

Mullins, H. T., Heath, K. C., Van Buren, H. M., and Newton, C. R., 1984. Anatomy of a modern open-ocean carbonate slope-Northern Little Bahama Bank: Sedimentology, 31:141-176.

Mullins, H. T., and Lynts, G. W., 1977. Origin of the northwestern Bahama platform: review and reinterpretation. Geol. Soc. Am. Bull., 88:1447-1461. 
Pinet, P. R., and Popenoe, P., 1985. A scenario of Mesozoic-Cenozoic ocean circulation over the Blake Plateau and its environs. Geol. Soc. Amer. Bull., 96:618-626.

Schlager, W., and Chermak, A., 1979. Sediment facies of platform-basin transition, Tongue of the Ocean, Bahamas. In Doyle, L., and Pilkey, O. H., (Eds.), Geology of Continental Slopes: SEPM Spec. Publ., 27:193-208.

Schlager, W., and Ginsburg, R. N., 1981. Bahama carbonate platformsthe deep and the past. Mar. Geol., 44:1-24.

Schmoker, J. W., and Halley, R. B., 1982. Carbonate porosity versus depth: a predictable relation for South Florida. AAPG Bull., 66: 2561-2570.

Sheridan, R. E., Crosby, J. T., Bryan, G. M., and Stoffa, P. L., 1981. Stratigraphy and structure of the southern Blake Plateau, northern Florida Straits and northern Bahama Platform from recent multichannel seismic reflection data. AAPG Bull., 65:2571-2593.
Talwani, M., Worzel, J. L., and Ewing, M., 1960. Gravity anomalies and structure of the Bahamas. Trans. 2nd Caribbean Geol. Conf., Puerto Rico, 156-160.

Williams, S. C., 1986. Stratigraphy, facies evolution and diagenesis of late Cenozoic limestones and dolomites, Little Bahama Bank, Bahamas [Ph. D. dissert]. Univ. Miami, Coral Gables, FL.

Winston, G. O., 1971. Regional structure, stratigraphy, and oil possibilities of the south Florida basin. Gulf Coast Assoc. Geol. Soc. Trans., 21:15-29.

Date of initial receipt: 26 January 1987

Date of acceptance: 29 July 1987

Ms 101B-163 